\title{
Prion Protein and Copper Cooperatively Protect Neurons by Modulating NMDA Receptor Through S-nitrosylation
}

\author{
Lisa Gasperini,, Elisa Meneghetti, Beatrice Pastore, Federico Benetti, ${ }^{1, *}$ and Giuseppe Legname ${ }^{1,2}$
}

\begin{abstract}
Aims: Several neurodegenerative disorders show alterations in glutamatergic synapses and increased susceptibility to excitotoxicity. Mounting evidence suggests a central role for the cellular prion protein $\left(\operatorname{PrP}^{\mathrm{C}}\right)$ in neuroprotection. Therefore, the loss of $\operatorname{PrP}^{\mathrm{C}}$ function occurring in prion disorders may contribute to the disease progression and neurodegeneration. Indeed, $\mathrm{PrP}^{\mathrm{C}}$ modulates $N$-methyl-D-aspartate receptors (NMDAR), thus preventing cell death. In this study, we show that $\mathrm{PrP}^{\mathrm{C}}$ and copper cooperatively inhibit NMDAR through S-nitrosylation, a post-translational modification resulting from the chemical reaction of nitric oxide (NO) with cysteines. Results: Comparing wild-type $\operatorname{Prnp}\left(\operatorname{Prnp}^{+/+}\right)$and $\operatorname{PrP}^{\mathrm{C}}$ knockout $\left(\operatorname{Prnp}^{0 / 0}\right)$ mouse hippocampi, we found that GluN1 and GluN2A S-nitrosylation decrease in $P r n p^{0 / 0}$. Using organotypic hippocampal cultures, we found that copper chelation decreases NMDAR Snitrosylation in $P_{r n p}{ }^{+/+}$but not in $P_{r n p}{ }^{0 / 0}$. This suggests that $\operatorname{PrP}^{\mathrm{C}}$ requires copper to support the chemical reaction between $\mathrm{NO}$ and thiols. We explored $\mathrm{PrP}^{\mathrm{C}}-\mathrm{Cu}$ neuroprotective role by evaluating neuron susceptibility to excitotoxicity in $\mathrm{Prnp}^{+/+}$and $\mathrm{Prnp}^{\mathrm{O} / 0}$ cultures. We found that (i) $\mathrm{PrP}^{\mathrm{C}}-\mathrm{Cu}$ modulates GluN2A-containing NMDAR, those inhibited by S-nitrosylation; (ii) $\operatorname{PrP}^{\mathrm{C}}$ and copper are interdependent to protect neurons from insults; (iii) neuronal NO synthase inhibition affects susceptibility in wild-type but not in $P_{r n p}{ }^{0 / 0}$, while (iv) the addition of a NO donor enhances Prnp ${ }^{0 / 0}$ neurons survival. Innovation and Conclusions: Our results show that $\operatorname{PrP}^{\mathrm{C}}$ and copper support NMDAR S-nitrosylation and cooperatively exert neuroprotection. In addition to NMDAR, $\operatorname{PrP}^{\mathrm{C}}$ may also favor the S-nitrosylation of other proteins. Therefore, this mechanism may be investigated in the context of the different cellular processes in which $\operatorname{PrP}^{\mathrm{C}}$ is involved. Antioxid. Redox Signal. 22, 772-784.
\end{abstract}

\section{Introduction}

T He CEllular PRION PROTEIN $\left(\operatorname{PrP}^{\mathrm{C}}\right)$ has been extensively investigated since its isoform, the prion, was identified as the causative agent of prion disorders (33). $\operatorname{PrP}^{\mathrm{C}}$ is widely expressed, reaching the highest levels in the nervous system $(3,12$, 31). Comparing wild-type with $\operatorname{PrP}^{\mathrm{C}}$-null mice $\left(\operatorname{Prnp}^{0 / 0}\right)$ has revealed that $\operatorname{PrP}^{C}$ expression at synapses contributes to hippocampus synaptic function $(6,27,28)$ and exerts neuroprotection by modulating neuronal excitability $(21,34,38)$. In particular, $\operatorname{PrP}^{\mathrm{C}}$ inhibits $N$-methyl-D-aspartate receptors (NMDAR) and requires copper for this effect $(21,40)$. Interestingly, $\mathrm{A} \beta$ oligomers induce neurotoxicity by blocking $\mathrm{PrP}^{\mathrm{C}}-\mathrm{Cu}$ modulation of NMDAR (40). Impairments in NMDAR regulation induce excitotoxicity, the neuronal cell death pathway triggered by massive calcium influx (10). Calcium ions enter the

\section{Innovation}

A major cause of neurodegeneration is the disruption of excitatory synapse regulation. Mounting evidence points to a central neuroprotective role for the cellular prion protein $\left(\mathrm{PrP}^{\mathrm{C}}\right)$, a key player in prion disorders and Alzheimer disease (AD). Here, we describe a novel neuroprotective mechanism mediated by $\mathrm{PrP}^{\mathrm{C}}$, copper, and nitric oxide: copper-bound $\mathrm{PrP}^{\mathrm{C}}$ modulates $N$-methyl-D-aspartate (NMDA)-type glutamate receptors by promoting $\mathrm{S}$-nitrosylation, inhibiting the ionic channel. This mechanism is likely blocked in prion disorders and $\mathrm{AD}$, thereby leading to neuron loss. $\operatorname{PrP}^{\mathrm{C}}$ function in protein S-nitrosylation may also guide the study of the numerous cellular pathways in which $\operatorname{PrP}^{\mathrm{C}}$ is involved.

${ }^{1}$ Laboratory of Prion Biology, Department of Neuroscience, Scuola Internazionale Superiore di Studi Avanzati (SISSA), Trieste, Italy. ${ }^{2}$ ELETTRA - Sincrotrone Trieste S.C.p.A, AREA Science Park, Trieste, Italy.

*Current affiliation: ECSIN-European Center for the Sustainable Impact of Nanotechnology, Veneto Nanotech S.C.p.A., Rovigo, Italy.

(C) Lisa Gasperini et al. 2015; Published by Mary Ann Liebert, Inc. This Open Access article is distributed under the terms of the Creative Commons Attribution Noncommercial License (http://creativecommons.org/licenses/by-nc/4.0/) which permits any noncommercial use, distribution, and reproduction in any medium, provided the original author(s) and the source are credited. 
cell through the NMDAR channel and bind several interactors, for example, calmodulin ( $\mathrm{CaM})$. Calcium-bound $\mathrm{CaM}$ activates neuronal nitric oxide synthase (nNOS) and induces copper-transporting ATPase 1 (Atp7a) translocation, thus leading to nitric oxide (NO) production and copper release in the synaptic cleft $(22,36)$. Copper and NO modulate the NMDAR activity through a not clearly defined mechanism: NMDAR Snitrosylation provides a link between copper and NO inhibitory roles $(7,23)$. S-nitrosylation is a chemical post-translational modification targeting protein cysteines. In NMDAR, Snitrosylation is inhibitory and addresses two residues on GluN1 and three residues on GluN2A, including Cys399, which mediates the predominant inhibitory effect. Copper released in the synaptic cleft is bound by metal-binding proteins, such as $\operatorname{PrP}^{\mathrm{C}}$, which binds copper with high affinity and sustains $\mathrm{Cu}(\mathrm{II})$ redox cycling $(5,8,24)$. In vitro results have shown that $\operatorname{PrP}^{\mathrm{C}}$-bound $\mathrm{Cu}$ (II) promotes $\mathrm{NO}$ oxidation and is consequently reduced to $\mathrm{Cu}(\mathrm{I})$ (4). As $\mathrm{PrP}^{\mathrm{C}}-\mathrm{Cu}$ is involved in glypican-1 heparan sulfate S-nitrosylation (29), the complex may also have a role in NMDAR S-nitrosylation.

Here, we show that $\operatorname{PrP}^{\mathrm{C}}$ exerts copper-dependent neuroprotection by mediating NMDAR S-nitrosylation. We define $\mathrm{PrP}^{\mathrm{C}}-\mathrm{Cu}$ direct involvement in NMDAR S-nitrosylation comparing GluN2A and GluN1 S-nitrosylation levels in Prnp ${ }^{+/+}$ and $P r n p^{0 / 0}$ hippocampi and cultures treated with a copper chelator. $\operatorname{PrP}^{\mathrm{C}}$ neuroprotective function is characterized comparing excitotoxicity susceptibility in different Prnp $^{+/+}$and Prnp $^{0 / 0}$ hippocampal areas. The copper/NO-dependence of $\operatorname{PrP}^{\mathrm{C}}$ neuroprotective activity is assessed observing the effects of copper chelation, NOS inhibition, and NO donation on neuronal death in wild-type and $P r n p^{0 / 0}$ cultures. We propose a model for this molecular mechanism based on the results presented here.

\section{Results}

\section{$\operatorname{PrP}^{C}$ is involved in NMDAR S-nitrosylation}

The S-nitrosylation of NMDAR extracellular cysteines may be a mechanism by which the $\mathrm{PrP}^{\mathrm{C}}-\mathrm{Cu}$ complex inhibits ion gating. To test this hypothesis, we measured GluN2A and GluN1 S-nitrosylation levels in adult Prnp $^{+/+}$and $P r n p^{0 / 0}$ hippocampi. To compare wild-type with $\mathrm{PrP}^{\mathrm{C}}$-null samples, the Western blotting signals corresponding to each $\mathrm{S}$-nitrosylated protein (i.e., GluN2A, GluN1 and $\beta$-Actin) were normalized against the respective input signals. Then, the obtained GluN2A and GluN1 ratio values were normalized against the corresponding $\beta$-actin ratio value, as an internal control. The resulting values for Prnp $^{+/+}$and Prnp ${ }^{0 / 0}$ hippocampi were compared by the MannWhitney test. In $\operatorname{PrP}^{\mathrm{C}}$-null hippocampus, we detected lower GluN2A $(n=9, p=0.0004)$ and GluN1 $(n=9, p=0.00203)$ Snitrosylation levels compared with those in the wild type (Fig. 1A, B). These findings show that in $\mathrm{PrP}^{\mathrm{C}}$-null hippocampus NMDAR S-nitrosylation is reduced. We confirmed these results by using an additional S-nitrosylation-detection method (Supplementary Materials and Methods and Supplementary Fig. S1; Supplementary Data are available online at www.liebert pub.com/ars). This observation suggests that $\operatorname{PrP}^{\mathrm{C}}$ is involved in GluN2A and GluN1 S-nitrosylation and, possibly through this mechanism, it can modulate the NMDAR activity.

To exclude that the results observed in $\operatorname{Prnp}^{0 / 0}$ hippocampus are due to different levels of either GluN2A-containing NMDAR or nNOS at synapses, we performed a co-immunoprecipitation (coIP) with the postsynaptic density protein 95 (PSD95). The
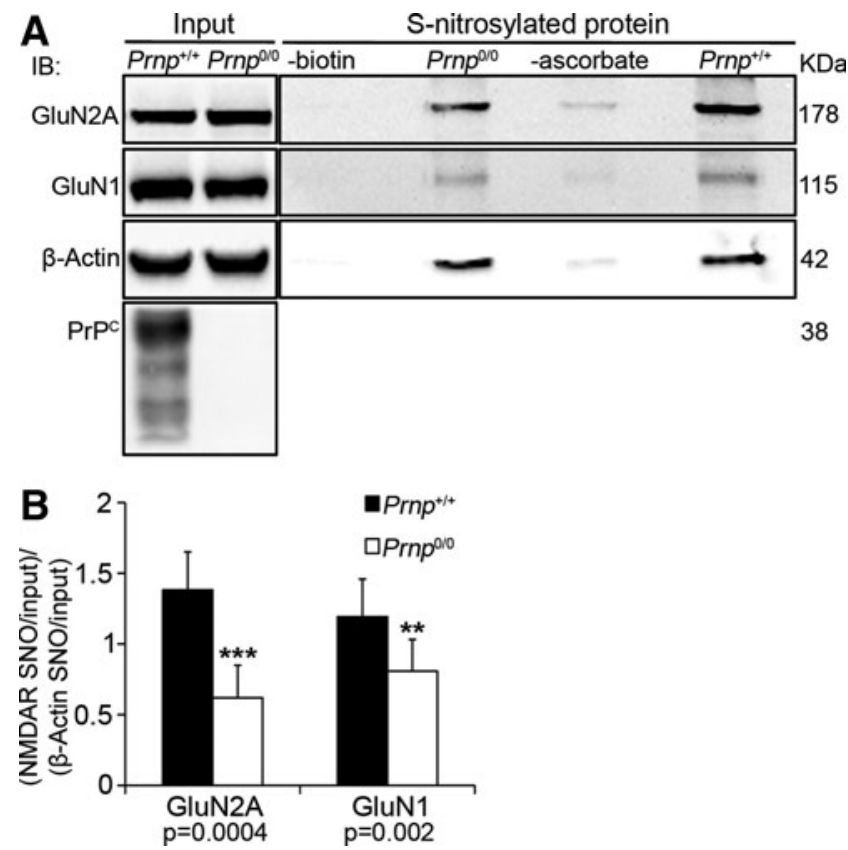

FIG. 1. In adult $\operatorname{Prnp}^{0 / 0}$ hippocampus, the S-nitrosylation of GluN2A and GluN1 NMDAR subunits is lower compared to wild type. (A) Signals of S-nitrosylated fraction, controls without either biotin or ascorbate and corresponding input of GluN2A, GluN1, and $\beta$-actin resulting from the biotin switch assay of Prnp ${ }^{+/+}$and Prnp ${ }^{0 / 0}$ hippocampus; controls without either biotin or ascorbate were done using Prnp $^{+/+}$samples. (B) Statistical analysis of S-nitrosylated GluN2A and GluN1 signals normalized on the corresponding input and on $\beta$-actin; all error bars indicate SD; $* * p<0.01$; ***p $<<0.001$. NMDAR, $N$ methyl-D-aspartate receptors.

results revealed comparable GluN2A (direct PSD95 interactor), GluN1 (indirect PSD95 interactor), and nNOS levels in Prnp $^{+/+}$and Prnp ${ }^{0 / 0}$ hippocampal synapses (Supplementary Materials and Methods and Supplementary Fig. S2A-C). Furthermore, to exclude that the results observed in Prnp ${ }^{0 / 0}$ hippocampus are due to altered NOS activity, first, we assessed the similarity of $\beta$-actin S-nitrosylation levels (Fig. 1A) and then measured both the consumption of NADPH, an essential cofactor for NO production, and the conversion of radiolabeled arginine to radiolabeled citrulline (Supplementary Materials and Methods). Adult Prnp ${ }^{+/+}$and Prnp ${ }^{0 / 0}$ samples exhibited comparable kinetics for NADPH consumption and the same capability to convert arginine to citrulline (Supplementary Fig. S3A, C). Taken together, these results suggest that the decreased NMDAR S-nitrosylation in $\operatorname{PrP}^{\mathrm{C}}$-null hippocampus is not due to a reduction in the levels of NMDAR and nNOS at synapses or alterations in NO production.

\section{In the absence of $\operatorname{PrP}^{C}$, hippocampal neurons} are more susceptible to NMDAR-mediated excitotoxicity

Since $P_{r n p}{ }^{0 / 0}$ hippocampus shows lower NMDAR Snitrosylation (Fig. 1 and Supplementary Fig. S1) but the same protein level at synapses (Supplementary Fig. S2A, C), $\operatorname{PrP}^{\mathrm{C}}$ null neurons should be more susceptible to excitotoxic treatment. To investigate the neuroprotective role of $\mathrm{PrP}^{\mathrm{C}}$ through glutamate receptor inhibition, we carried out excitotoxicity studies on Prnp $^{+/+}$and Prnp ${ }^{0 / 0}$ organotypic hippocampal 
cultures (OHC) by analyzing specifically neuronal death in Cornus Ammonis 1 (CA1), Cornus Ammonis 3 (CA3), and dentate gyrus (DG). We exposed Prnp ${ }^{+/+}$and Prnp $^{0 / 0} \mathrm{OHC}$ to two toxic treatments with NMDA as selective NMDAR agonist: $5 \mu M$ NMDA for $3 \mathrm{~h}$ (prolonged insult) and $10 \mu M$ NMDA for 10 min (acute insult). We chose these two protocols after observing that they induce low neuronal cell death levels in wild-type samples, hence they can clearly reveal a different susceptibility of $\operatorname{Prnp}^{0 / 0}$ samples. Neuronal cell death was evaluated as pyknotic nuclei percentage over the total number of nuclei in CA1, CA3, and DG, respectively. The concomitant staining with the anti-neuronal nuclei marker antibody (NeuN) allowed us to localize the pyknotic event in neurons and clearly distinguished glia cells. Figure 2A-M shows the different
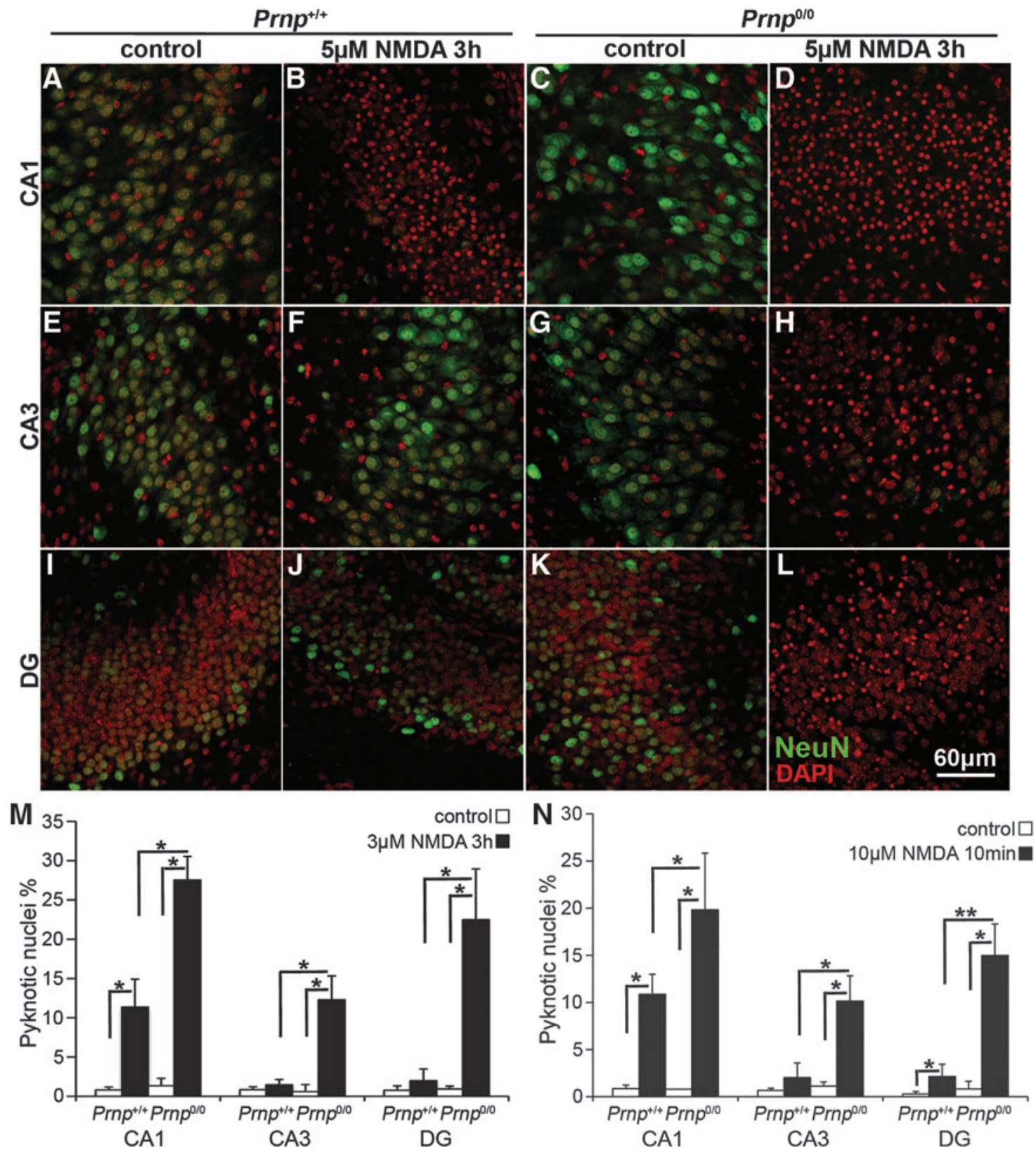

FIG. 2. Wild-type and $\operatorname{PrP}^{\mathrm{C}}$-null OHC show different regional susceptibility to NMDA treatment, under both prolonged and acute insult. Images from three hippocampal regions are reported in rows: (A-D) CA1, (E-H) CA3, and (I-L) DG.

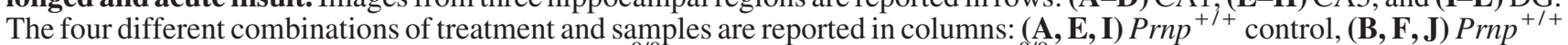
treated with $5 \mu M$ NMDA for $3 \mathrm{~h},(\mathbf{C}, \mathbf{G}, \mathbf{K}) \operatorname{Prnp}^{0 / 0}$ control, and $(\mathbf{D}, \mathbf{H}, \mathbf{L})$ Prnp $^{0 / 0}$ treated with $5 \mu M$ NMDA for 3 h. NeuN staining is displayed in green and DAPI in red. Confocal microscope fluorescence images were acquired using a $40 \times / 1.30 \mathrm{NA}$ oil objective. Comparison of the neuronal pyknotic nuclei percentage induced by $5 \mu M$ NMDA for $3 \mathrm{~h}(\mathbf{M} ; n=4 \mathrm{OHC}, 5 \mathrm{slices}$ per treatment in each culture) and by $10 \mu M$ NMDA for $10 \min (\mathbf{N} ; n=5 \mathrm{OHC}, 5$ slices per treatment in each culture $)$, calculated over the total nuclei number, between Prnp ${ }^{+/+}$(white bars) and Prnp ${ }^{0 / 0}$ (black bars) OHC in CA1, CA3, and DG; all error bars indicate SD; ${ }^{*} p<0.05,{ }^{* *} p<0.01$. CA1, Cornus Ammonis 1; CA3, Cornus Ammonis 3; DAPI, 4',6-diamidino-2-phenylindole; DG, dentate gyrus; OHC, organotypic hippocampal cultures. To see this illustration in color, the reader is referred to the web version of this article at www.liebertpub.com/ars 
responses of $\mathrm{Prnp}^{+/+}$and $\mathrm{Prnp}^{0 / 0} \mathrm{OHC}$ to the prolonged treatment ( $n=4 \mathrm{OHC}, 5$ slices per treatment in each culture). In CA1, the NMDA exposure significantly induced neuronal cell death in both Prnp $^{+/+}(p=0.03038)$ and $\operatorname{Prnp}^{0 / 0}(p=0.03038)$ OHC (Fig. 2A-D, M), but at the same time, it revealed a higher susceptibility of $\operatorname{Prnp}^{0 / 0} \mathrm{OHC}(p=0.03038)$. The NMDA treatment did not induce significant neuronal cell death in wild-type CA3 and DG, whereas it yielded high toxicity for both regions in $\mathrm{PrP}^{\mathrm{C}}$-null cultures (CA3, $p=0.03038$; DG, $p=0.03038$ ), highlighting a significant difference between Prnp $^{+/+}$and Prnp ${ }^{0 / 0}$ (CA3, $p=0.03038$; DG, $p=0.01996$ ) (Fig. 2E-M). The same quantitative differences between Prnp $^{+/+}$and Prnp ${ }^{0 / 0}$ OHC were observed following the acute treatment (Fig. $2 \mathrm{~N} ; n=5 \mathrm{OHC}, 5$ slices per treatment in each culture). In CA1, $10 \mu M$ NMDA for $10 \mathrm{~min}$ induced neuronal cell death in both $\operatorname{Prnp}^{+/+}(p=$ 0.01996) and $\operatorname{Prnp}^{0 / 0}(p=0.01996)$ OHC, but it revealed a higher susceptibility of $P r n p^{0 / 0}$ compared with Prnp ${ }^{+/+}$ ( $p=0.02157)$. In CA3, the acute treatment was toxic only for $\operatorname{Prnp}^{0 / 0} \mathrm{OHC}(p=0.03038)$, confirming their higher susceptibility compared with Prnp ${ }^{+/+}(p=0.01421)$. The wild-type DG showed low levels of neuronal cell death in response to the acute insult $(p=0.02518)$, whereas the same treatment caused a greater cell death percentage ( $p=0.01421)$ in $\operatorname{Prnp}^{0 / 0} \mathrm{DG}$, leading to a higher damage compared to Prnp ${ }^{+/+}(p=0.00507)$. The enhanced sus- ceptibility of $\mathrm{Prnp}^{0 / 0}$ neurons to the excitotoxic stimulus confirms findings previously reported in the literature, obtained by stimulating neurons with kainate (34) and NMDA (21).

To evaluate the early changes in neuronal cell viability, the MTT (thiazolyl blue tetrazolium bromide) mitochondrial toxicity assay was performed on Prnp ${ }^{+/+}$and Prnp ${ }^{0 / 0} \mathrm{OHC}$ after exposure to $5 \mu M$ NMDA for $3 \mathrm{~h}$. Results revealed that $\operatorname{Prnp}^{0 / 0} \mathrm{OHC}$ are more susceptible to excitotoxicity also in the early phases after insult (Supplementary Materials and Methods and Supplementary Fig. S4).

The excitotoxic mechanism induced by NMDAR overactivation is triggered by calcium ion influx into the neuronal cell (10). To verify that the excitotoxicity observed was a calcium-mediated effect, the same treatments were performed adding a calcium chelator, ethylene glycol tetraacetic acid (EGTA; $n=3 \mathrm{OHC}, 4$ slices per treatment in each culture). It should be noted that the treatment with $5 \mu M$ NMDA was shortened to $1.5 \mathrm{~h}$ since calcium deprivation for $3 \mathrm{~h}$ resulted to be toxic per se. As expected, adding EGTA to NMDA abolished neuronal cell death in all the analyzed regions and under both prolonged and acute insults (Fig. 3A-C and Supplementary Fig. S5A-I; Prn ${ }^{+/+}$CA1: $p=0.03038$ and $p=0.03038 ;$ Prnp $^{0 / 0}$ CA $1: p=0.01996$ and $p=0.03038$; $\operatorname{Prnp}^{0 / 0}$ CA3: $p=0.01894$ and $p=0.0294 ; \operatorname{Prnp}^{0 / 0}$ DG: $p=0.01945$ and $p=0.01996)$. Shortening the exposure time
FIG. 3. Neuronal cell death induced by NMDA treatment is prevented by calcium chelation and NMDAR antagonist, unaltered by AMPA/kainate receptor and GluN2B-containing NMDAR antagonists. Comparison of NMDAinduced neuronal pyknotic nuclei percentages between EGTA-treated Prnp ${ }^{+/+}$and Prnp ${ }^{0 / 0} \mathrm{OHC}$ in the (A) CA1, (B) CA3, and (C) $\mathrm{DG} ; n=3$ OHC, 5 slices per treatment in each culture. Comparison of NMDA-induced neuronal pyknotic nuclei percentages between NMDAR inhibitors (AP5 and/or CNQX)-treated Prnp ${ }^{+/+}$ and $P r n p^{0 / 0} \mathrm{OHC}$ in the (D) CA1, (E) CA3, and (F) DG; $n=4 \mathrm{OHC}$, 5 slices per treatment in each culture. Comparison of NMDA-induced neuronal pyknotic nuclei percentages between GluN2B inhibitor (ifenprodil)-treated Prnp $^{+/+}$and Prnp ${ }^{0 / 0}$ $\mathrm{OHC}$ in the $(\mathbf{G}) \mathrm{CA} 1,(\mathbf{H}) \mathrm{CA} 3$, and (I) $\mathrm{DG} ; n=4 \mathrm{OHC}, 5$ slices per treatment in each culture. All error bars indicate SD; $* p<0.05$. AMPA, $\alpha$-amino-3-hydroxy-5-methyl-4isoxazolepropionic acid; AP5, (2R)amino-5-phosphonovaleric acid; CNQX, 6-cyano-7-nitroquinoxaline-2,3-dione; EGTA, ethylene glycol tetraacetic acid. To see this illustration in color, the reader is referred to the web version of this article at www.liebertpub.com/ars
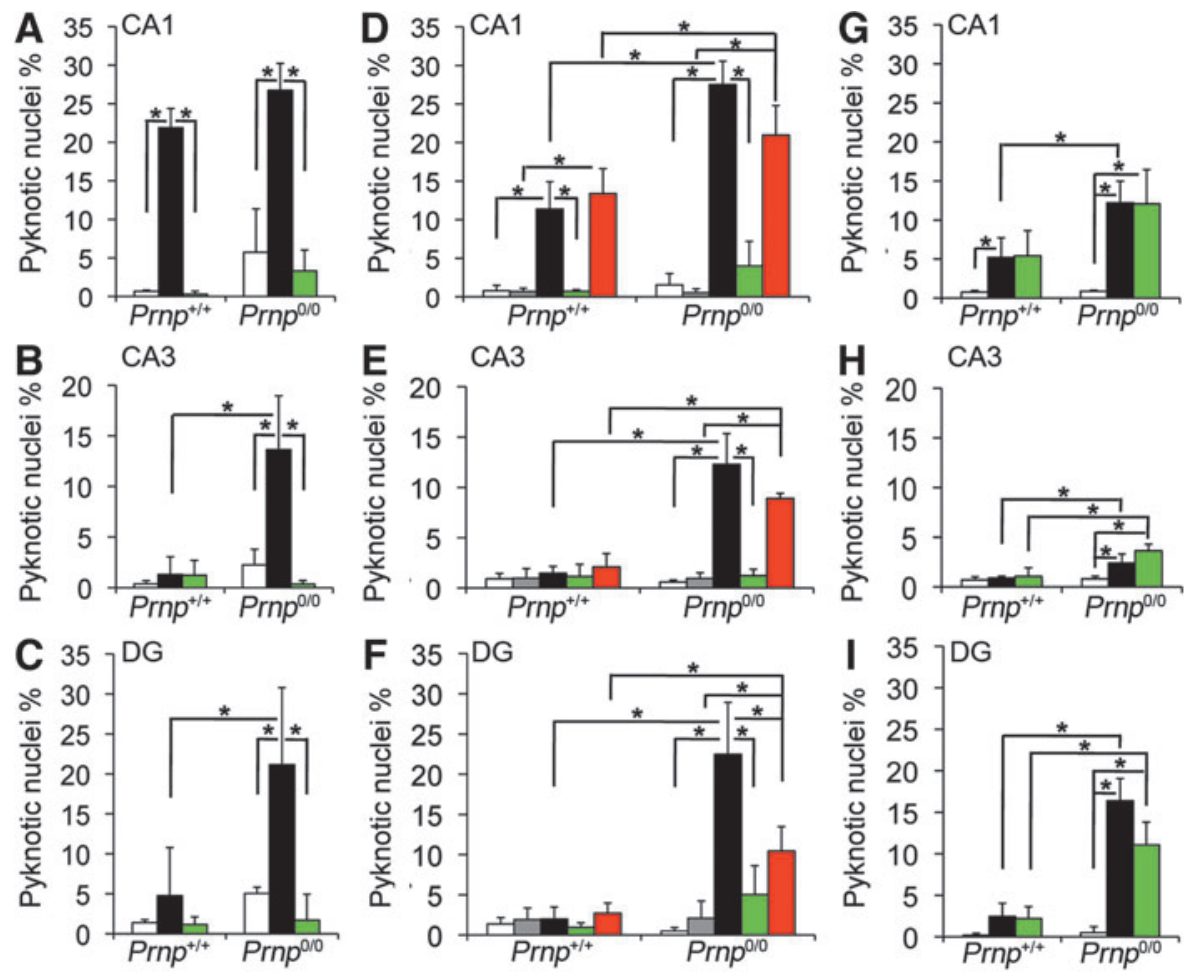

口2mM EGTA $1.5 \mathrm{~h}$ - $5 \mu \mathrm{M}$ NMDA $1.5 \mathrm{~h}$ $\square 5 \mu \mathrm{M} N M D A+2 \mathrm{mM}$ EGTA 1.5h

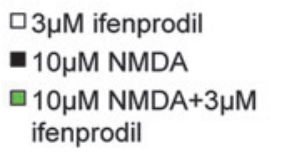

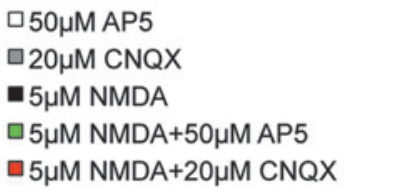


to $5 \mu M$ NMDA did not affect the differences between Prnp $^{+/+}$and Prnp ${ }^{0 / 0} \mathrm{OHC}$.

Next, we assessed the primary involvement of NMDAR in the neurotoxic mechanism $(n=4 \mathrm{OHC}, 5$ slices per treatment in each culture). Adding the NMDAR blocker AP5 to $5 \mu M$ NMDA for $3 \mathrm{~h}$ abolished cell death (Fig. 3D-F and Supplementary Fig. S6A-F; Prnp ${ }^{+1+}$ CA1: $p=0.03038 ;$ Prnp $^{0 / 0}$ CA1: $p=0.03038$; Prnp $^{0 / 0}$ CA3: $p=0.03038 ;$ Prnp $^{0 / 0}$ DG: $p=0.03038$ ). In contrast, adding the $\alpha$-amino-3-hydroxy-5methyl-4-isoxazolepropionic acid (AMPA)/kainate receptor blocker 6-cyano-7-nitroquinoxaline-2,3-dione (CNQX) to $5 \mu M$ NMDA for $3 \mathrm{~h}$ did not diminish cell death in Prnp ${ }^{+/+}$ CA1, Prnp ${ }^{0 / 0} \mathrm{CA} 1$, and Prnp ${ }^{0 / 0} \mathrm{CA} 3$ (Fig. 3D, E and Supplementary Fig. S6A-D). However, adding CNQX to NMDA did reduce the pyknosis percentage in $\operatorname{Prnp}^{0 / 0} \mathrm{DG}(p=0.03038)$, suggesting a partial AMPA/kainate receptor involvement (Fig. 3F and Supplementary Fig. S6E, F). Overall, despite the AMPA/kainate receptor inhibition, the higher cell death levels in $\mathrm{PrP}^{\mathrm{C}}$-null were maintained, confirming a primary involvement of NMDAR. To assess whether the neurotoxic effect was mainly due to either GluN2A- or GluN2Bcontainig NMDAR, we used ifenprodil, a selective inhibitor of GluN2B. The excitotoxic condition applied was $10 \mu M$ NMDA for 10 min since ifenprodil has an aspecific toxic effect if added to lower NMDA concentrations (20). In both Prnp $^{+/+}$and Prnp ${ }^{0 / 0} \mathrm{OHC}$, ifenprodil did not reduce the cell death levels observed with NMDA alone, suggesting that the overactivation of GluN2B-containing receptor is not the leading cause for neuronal death (Fig. 3G-I and Supplementary Fig. S7). A major involvement of GluN2Acontaining receptor is therefore a more likely hypothesis.

\section{Copper ions are required for $\operatorname{PrP}^{C}$ to support NMDAR S-nitrosylation}

Copper ions are fundamental in the S-nitrosylation reaction because their reduction from $\mathrm{Cu}(\mathrm{II})$ to $\mathrm{Cu}(\mathrm{I})$ allows for the oxidation of $\mathrm{NO}$ and its ensuing reaction with cysteine thiols $(11,17)$. Because $\mathrm{PrP}^{\mathrm{C}}$-bound $\mathrm{Cu}(\mathrm{II})$ promotes $\mathrm{NO}$ oxidation (4), $\mathrm{PrP}^{\mathrm{C}}$ is likely to promote NMDAR S- nitrosylation through the copper ions it binds. To verify this mechanism, we measured GluN2A and GluN1 S-nitrosylation levels in Prnp ${ }^{+/+}$and Prnp ${ }^{0 / 0} \mathrm{OHC}$ upon treatment with cuprizone $(\mathrm{CZ})$, a selective copper chelator that binds $\mathrm{Cu}^{2+}$. Since $\mathrm{Cu}^{2+}$ promotes $\mathrm{S}$-nitrosylation while $\mathrm{Cu}^{+}$triggers denitrosylation, $\mathrm{CZ}$ treatment specifically blocks S-nitrosylation induction. $\mathrm{CZ}$ does not affect neuronal viability and cannot cross plasma membranes (2); hence, it should not affect cytoplasmic protein S-nitrosylation. Indeed, $\beta$-actin Snitrosylation levels were comparable among control and $\mathrm{CZ}$ treated wild-type and $\mathrm{PrP}^{\mathrm{C}}$-null $\mathrm{OHC}$, providing us with a reliable internal control for the normalization of NMDAR Snitrosylation signal. Moreover, we used serum-free medium to avoid copper content variability and thereby ensure uniform copper chelation. In serum-free medium, CZ binds copper ions released in the synaptic cleft (36), thus affecting the coppermediated S-nitrosylation in the extracellular environment. Prnp $^{+/+}$and Prnp ${ }^{0 / 0}$ OHC were exposed to $20 \mu M \mathrm{CZ}$ for $3 \mathrm{~h}$, immediately frozen, and then processed for the detection of Snitrosylated proteins. As already observed in the hippocampus, GluN2A and GluN1 S-nitrosylation was decreased in Prnp ${ }^{0 / 0}$ samples (Fig. 4A, B; $n=4$ slice pools, $p=0.03038$ and $p=0.03038$, respectively). Consistent with the hypothesized mechanism, CZ addition reduced GluN2A and GluN1 Snitrosylation in Prnp ${ }^{+/+} \mathrm{OHC}(p=0.03038$ and $p=0.03038$, respectively) but not in $P_{r n p}{ }^{0 / 0}$ ones (Fig. 4A, B). Furthermore, NMDAR S-nitrosylation levels in CZ-treated wild-type $\mathrm{OHC}$ were not different from either control or CZ-treated Prnp ${ }^{0 / 0}$ samples. This result shows that $\mathrm{CZ}$ addition affects NMDAR Snitrosylation only in wild type but not in $\operatorname{Prnp}^{0 / 0} \mathrm{OHC}$; hence, it strongly suggests that the lower S-nitrosylation of NMDAR subunits in Prnp ${ }^{0 / 0}$ samples is due to the lack of the $\operatorname{PrP}^{\mathrm{C}}-\mathrm{Cu}$ complex and that $\operatorname{PrP}^{\mathrm{C}}$-bound copper ions favor the $\mathrm{S}$ nitrosylation of NMDAR. Residual GluN1 and GluN2A Snitrosylation is due to $\operatorname{PrP}^{\mathrm{C}}$-independent mechanisms.

To rule out that the results observed in $\operatorname{Prnp}^{0 / 0} \mathrm{OHC}$ are due to different levels of GluN2A-containing NMDAR and nNOS at synapses, we performed coIP assays with PSD95 using hippocampi from postnatal day 20 (P20) mice. This age was selected because it is close to the developmental stage of $\mathrm{OHC}$

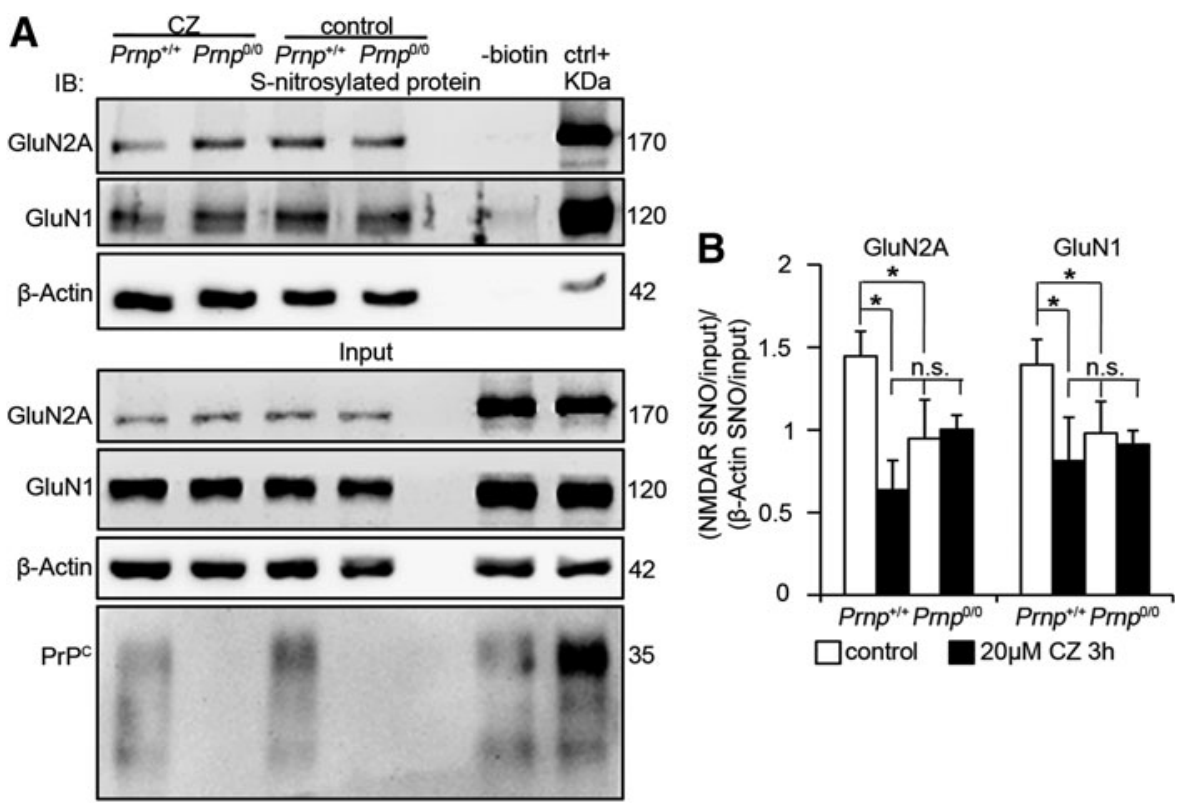

FIG. 4. Copper chelation decreases S-nitrosylation of GluN2A and GluN1 in wild type but not in Prnp $^{\text {0/0 }}$ OHC. (A) Signals of Snitrosylated fraction and corresponding input of GluN2A, GluN1, and $\beta$-actin resulting from the biotin switch assay of Prnp ${ }^{+/+}$and Prnp ${ }^{0 / 0}$ $\mathrm{OHC}$, treated and untreated with $\mathrm{CZ}$; adult wild-type hippocampus was used as negative (- biotin) and positive control. (B) Statistical analysis of S-nitrosylated GluN2A and GluN1 signals normalized on the corresponding input and on $\beta$-actin; all error bars indicate SD; sample size $n=4 ;{ }^{*} p<0.05$, n.s., not statistically significant difference. CZ, cuprizone. 
at the time of the treatment. The results revealed comparable GluN2A, GluN1, and nNOS levels in P20 Prnp ${ }^{+/+}$and Prnp ${ }^{0 / 0}$ hippocampal synapses (Supplementary Fig. S8A-C). Also, at this developmental stage, we reasoned to exclude that the results observed in Prnp ${ }^{0 / 0} \mathrm{OHC}$ were due to different levels of NOS activity. Like in the adult hippocampus, we observed that $\beta$-actin S-nitrosylation levels were similar in control and CZ-treated Prnp ${ }^{+/+}$and Prnp ${ }^{0 / 0}$ OHC (Fig. 4A). Next, we measured the consumption of NADPH and the conversion of radiolabeled arginine to radiolabeled citrulline in P20 samples and found comparable results in Prnp ${ }^{+/+}$and Prnp ${ }^{0 / 0}$ hippocampi (Supplementary Fig. S3B, C).

\section{The neuroprotective function of $\operatorname{Pr} P^{C}$ is copper-dependent}

So far, we have shown that in $\operatorname{Prnp}^{0 / 0}$ mouse OHC, NMDAR S-nitrosylation is not mediated by copper since it is not lowered by $\mathrm{CZ}$ addition. However, $\mathrm{CZ}$ treatment decreases NMDAR S-nitrosylation in Prnp $^{+/+}$mouse OHC to the level detected in Prnp ${ }^{0 / 0}$ mouse OHC (Fig. 4). Since extracellular cysteine S-nitrosylation inhibits NMDAR by lowering the frequency of channel opening (23), we measured intracellular calcium $\left[\mathrm{Ca}^{2+}\right]_{i}$ waves in wild-type mouse hippocampal neurons upon treatment with $20 \mu M \mathrm{CZ}, 5 \mu M$ NMDA, and $5 \mu M$ NMDA $+20 \mu M \mathrm{CZ}$ (Supplementary Materials and Methods). We found that both $\mathrm{CZ}$ and NMDA triggered $\left[\mathrm{Ca}^{2+}\right]_{i}$ waves, but the addition of $\mathrm{CZ}$ to NMDA induced a much higher $\left[\mathrm{Ca}^{2+}\right]_{\mathrm{i}}$ increase (Supplementary Fig. S9). These results indicate that copper chelation enhances NMDAR channel opening. Consistent with this finding, it has been reported that, upon copper chelation, wild-type hippocampal neurons exhibit nondesensitizing NMDAR currents comparable to those registered in $\operatorname{Prnp}^{0 / 0}$ (40). Therefore, we studied the neurotoxic effects of NMDA exposure in Prnp ${ }^{+/+}$ and $P_{r n p}{ }^{0 / 0} \mathrm{OHC}$ in the presence of $\mathrm{CZ}(n=4 \mathrm{OHC}, 5$ slices per treatment in each culture). $\mathrm{CZ}$ treatment without NMDA did not induce neuronal cell death in neither Prnp $^{+/+}$nor Prnp $^{0 / 0}$ OHC (Supplementary Fig. S10A-F). Our results confirm the neuroprotective function of $\mathrm{PrP}^{\mathrm{C}}$ through a copper-dependent inhibition of NMDAR (Fig. 5). In wild-type $\mathrm{OHC} \mathrm{CA} 1$, copper chelation did not enhance significantly the pyknosis, but it abolished the difference with $\mathrm{PrP}^{\mathrm{C}}$-null OHC CA1 (Fig. 5A, G). In wild-type OHC CA3 and DG, CZ addition to NMDA significantly increased neuronal cell death (Fig. 5C, E, H, I; $p=0.01219, p=$ 0.02157). In contrast, in $P_{r n p}{ }^{0 / 0}$ CA1 and DG, the copper chelator did not alter the susceptibility of neurons to NMDA (Fig. 5 B, F, G, I), whereas in Prnp ${ }^{0 / 0}$ CA3, it did decrease neuronal cell death (Fig. 5D, H; $p=0.01219$ ). This partial neuroprotection exerted by CZ in $P r n p^{0 / 0} \mathrm{CA} 3$ may be related to a toxic effect triggered by copper ions released after NMDAR activation in the absence of $\operatorname{PrP}^{\mathrm{C}}$. These results indicate that copper is neuroprotective in wild-type mouse $\mathrm{OHC}$; on the contrary, this effect is greatly reduced in $\mathrm{PrP}^{\mathrm{C}}$ null $\mathrm{OHC}$, thus suggesting that $\operatorname{PrP}^{\mathrm{C}}$ and copper can contribute to neuroprotection only if simultaneously present.

\section{The neuroprotective function of $\mathrm{PrP}^{C}$ is NO-dependent}

Next, we verified the involvement of $\mathrm{NO}$ in $\mathrm{PrP}^{\mathrm{C}}$ neuroprotective function. To this aim, we studied the neurotoxic effect of NMDA exposure in Prnp ${ }^{+/+}$and Prnp ${ }^{0 / 0}$ OHC in the presence of either $\mathrm{N} \omega$-nitro-L-arginine (NNA), which blocks NO production by all NO synthase isoforms (i.e., nNOS, endothelial NOS, and inducible NOS) or Snitrosoglutathione (GSNO), a NO donor ( $n=4 \mathrm{OHC}, 5$ slices per treatment in each culture). Both NNA and GSNO had no toxic effect (Supplementary Fig. S10A-F). NOS inhibition by NNA significantly enhanced cell death in all the analyzed regions in wild-type hippocampal cultures (Fig. 6A, C, E, G-I; $p=0.03038, p=0.03038, p=0.03038$ ), while it had no effect in $\mathrm{PrP}^{\mathrm{C}}$-null $\mathrm{OHC}$ (Fig. 6B, D, F, G-I). GSNO addition to NMDA significantly increased neuronal cell survival in all the analyzed regions in $\mathrm{PrP}^{\mathrm{C}}$-null $\mathrm{OHC}$ (Fig. 6B, D, F, G-I; $p=0.01996, p=0.03038, p=0.03038)$ and also in wild-type CA1 region (Fig. 6A, G; $p=0.03038$ ).

These results indicate that NOS production of NO is necessary to mediate $\operatorname{PrP}^{\mathrm{C}}$ neuroprotective function.

\section{Discussion}

Determining the function of $\operatorname{PrP}^{C}$ is of utmost importance to understand different neurodegeneration mechanisms, in particular those underlying prion disorders and Alzheimer disease (AD). In prion disorders, the loss of $\mathrm{PrP}^{\mathrm{C}}$ function upon protein aggregation may contribute to the pathology progression (1). $\operatorname{PrP}^{\mathrm{C}}$ has been found to play a role also in $\mathrm{AD}$ (19), where it has been involved in pathological mechanisms together with copper and NMDAR. Recent results indicate that the interaction with $\mathrm{A} \beta$ oligomers prevents the $\mathrm{PrP}^{\mathrm{C}}-\mathrm{Cu}$ complex-mediated inhibition of NMDAR, leading to overactivation of the ion channel (40). Zamponi and colleagues propose that $\operatorname{PrP}^{\mathrm{C}}$ bound to copper limits excessive NMDAR activity by reducing the receptor affinity for glycine. In the present work, we put forward an additional mechanism in which $\mathrm{PrP}^{\mathrm{C}}-\mathrm{Cu}$ modulates NMDAR together with NO. The novelty of this study is represented by the description of the functional interaction of $\operatorname{PrP}^{\mathrm{C}}$, copper, and NO. The relevance of copper, NO, and NMDAR overactivation in processes that lead to synapse loss in AD is widely accepted (15). In light of these premises, the mechanism we present here may help our understanding of the pathological processes involved in the progression of both $\mathrm{AD}$ and prion disorders.

Here, we argue that $\operatorname{PrP}^{\mathrm{C}}$ protects glutamatergic synapses from excitotoxic insults by promoting NMDAR S-nitrosylation. Figure 7 shows the proposed model for NMDAR inhibition by $\operatorname{PrP}^{\mathrm{C}}$. Glutamate released from the presynaptic terminal activates NMDAR with ensuing calcium influx. In the intracellular compartment, calcium binds to $\mathrm{CaM}$, and the $\mathrm{Ca}^{2+} / \mathrm{CaM}$ complex activates, among others, nNOS and Atp7a (22, 36); NO and copper are thus released in the synaptic cleft. Because of $\mathrm{PrP}^{\mathrm{C}}$ high affinity to copper ions (8) and high expression levels in hippocampal synapses $(31,35)$, it is likely to bind copper released in the synaptic cleft. In this milieu, $\mathrm{PrP}^{\mathrm{C}}$-bound $\mathrm{Cu}$ (II) can oxidize $\mathrm{NO}$ to $\mathrm{NO}^{+}$and be reduced to $\mathrm{Cu}(\mathrm{I})$ (4). This reaction enables the electrophilic attack of $\mathrm{NO}^{+}$on GluN2A and GluN1 extracellular cysteine thiol groups, resulting in the S-nitrosylation of NMDAR. coIP experiments of $\operatorname{PrP}^{\mathrm{C}}$ with NMDAR subunits have yielded positive results (40), confirming the proximity of $\operatorname{PrP}^{\mathrm{C}}$ and NMDAR subunits in lipid rafts $(9,32)$. The experimental evidence we present here supports this molecular mechanism.

NMDAR regulation operated by NO reduces significantly the neurotoxic effect induced by the overactivation of the 

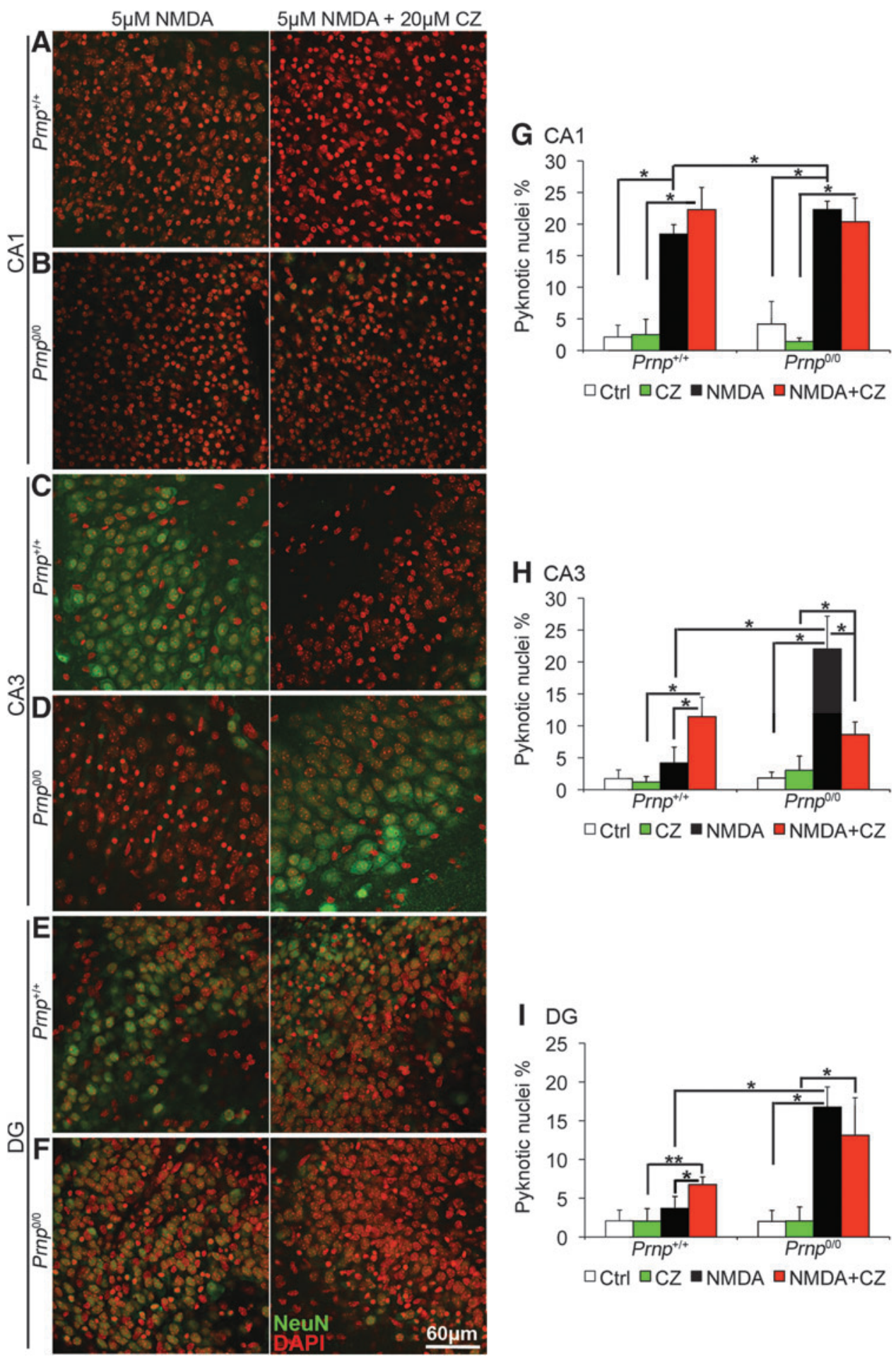

FIG. 5. Copper chelation increases neuronal cell death in Prnp ${ }^{+/+}$OHC but not in Prnp ${ }^{00}$. Images from Prnp $^{+/+}$and Prnp ${ }^{8 / 0} \mathrm{OHC}$ areas are reported in rows: (A) Prnp $^{+++}$CA1; (B) $\operatorname{Prnp}^{0 / 0}$ CA1; (C) Prnp ${ }^{+/+}$ CA3; (D) Prnp ${ }^{0 / 0}$ CA3; (E) Prnp $^{++}$DG; (F) Prnp $^{0 / 0}$ DG. The different treatments are reported in columns: $5 \mu M$ NMDA for $3 \mathrm{~h}$, left column; $5 \mu M$ NMDA +20 $\mu M \mathrm{CZ}$ for $3 \mathrm{~h}$, right column. NeuN staining is displayed in green and DAPI in red. Confocal microscope fluorescence images were acquired using a $40 \times / 1.30 \mathrm{NA}$ oil objective. Graphs show the comparison of the neuronal pyknotic nuclei percentage, calculated over the total nuclei number, between Prnp $^{+/+}$and Prnp ${ }^{0 / 0} \mathrm{OHC}$ in CA1 (G), CA3 (H), and DG (I); all error bars indicate $\mathrm{SD}$; sample size $n=4 \mathrm{OHC}$, 5 slices per treatment in each culture; $* p<0.05, * * p<0.01$. To see this illustration in color, the reader is referred to the web version of this article at www.liebertpub.com/ars
NMDAR-coupled ionic channel and the ensuing excessive calcium entry (30). S-nitrosylation diminishes the amplitude of NMDAR-evoked currents by reducing the number of channel openings (23). By comparing GluN2A and GluN1 $\mathrm{S}$-nitrosylation levels in wild-type and $\mathrm{PrP}^{\mathrm{C}}$-null mouse hippocampi, we found that, in absence of $\operatorname{PrP}^{\mathrm{C}}$, NMDAR Snitrosylation levels are decreased. S-nitrosylation can proceed through different routes not involving copper (14), and $\mathrm{PrP}^{\mathrm{C}}$ $\mathrm{Cu}$ is not the only complex able to support the copper-mediated reaction; otherwise, no S-nitrosylated NMDAR signal would be detectable in $\operatorname{PrP}^{\mathrm{C}}$-null samples. However, the extent of the reduction observed is remarkable, indicating that $\mathrm{PrP}^{\mathrm{C}}-\mathrm{Cu}$ is a key player in this post-translational modification on NMDAR.

Since S-nitrosylation limits NMDAR overactivation, thus staving off apoptosis, $\operatorname{PrP}^{\mathrm{C}}$-null neurons should be more susceptible to excitotoxicity. Consistent with this observation and with results reported in the literature (21), we found that $\mathrm{PrP}^{\mathrm{C}}$ ablation strongly impairs neuronal survival upon toxic exposure to NMDA. By applying a pool of glutamate receptors antagonists, we found that GluN2A-containing NMDAR 


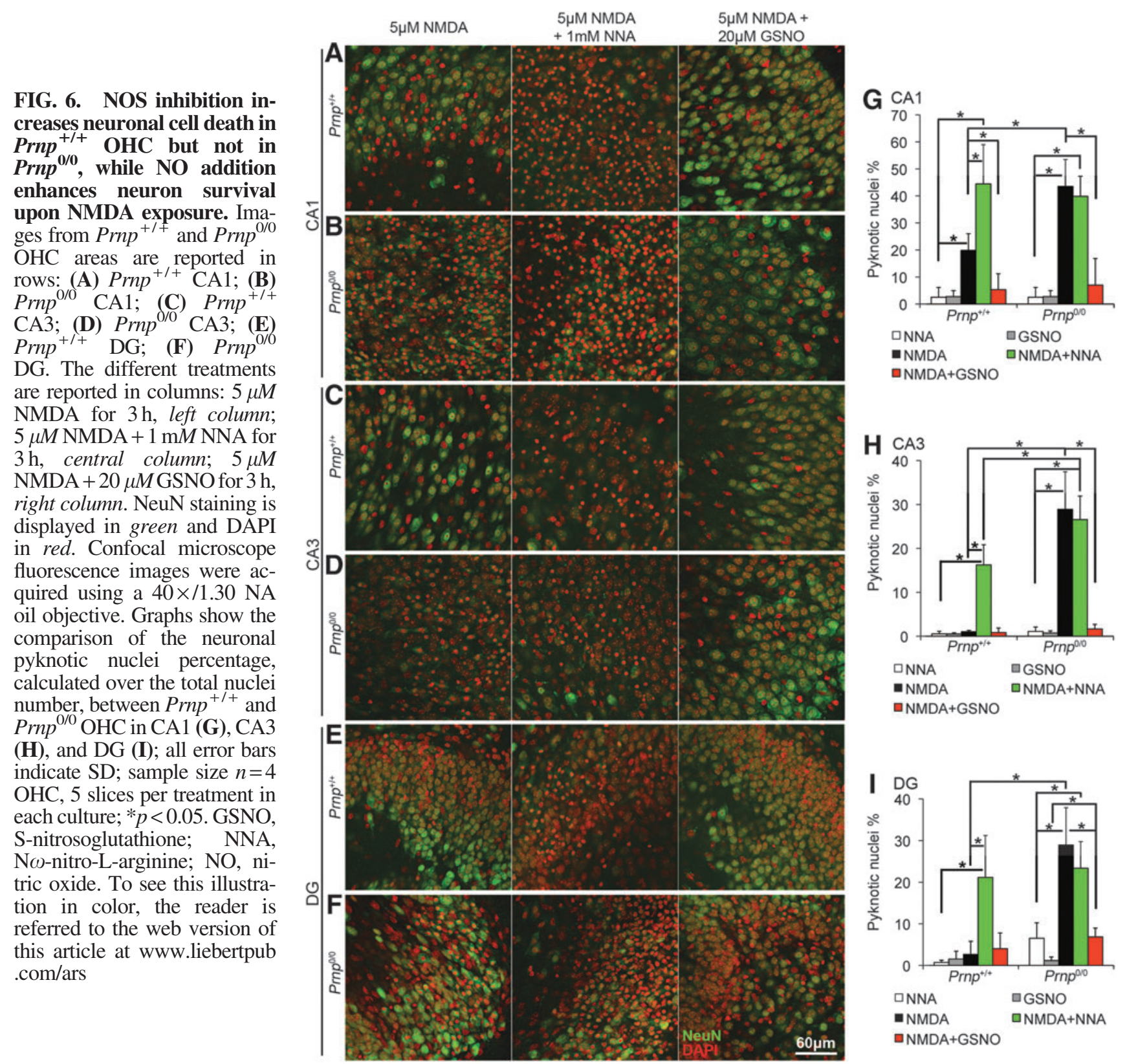

were mainly responsible for increasing the cell death level in $\operatorname{PrP}^{\mathrm{C}}$-null neurons. These results contrast with the notion that GluN2B-enriched extrasynaptic receptors may be key mediators of neuron death (16). However, growing evidence supports an involvement of both GluN2A and GluN2B in synaptic and extrasynaptic NMDAR-mediated excitotoxicity $(39,41,42)$. Therefore, it is plausible that a dysfunction in GluN2A inhibition causes higher neuron death in $\operatorname{PrP}^{\mathrm{C}}$-null mouse OHC. Interestingly, GluN2A is the subunit containing the cysteine residue that mediates the predominant inhibitory effect of $\mathrm{NO}(7,23)$. This regulation provides a clear link between the increased neuron death level and the lower NMDAR S-nitrosylation detected in $\operatorname{PrP}^{\mathrm{C}}$-null mouse hippocampus. In situ hybridization experiments have shown that $\mathrm{PrP}^{\mathrm{C}}$ knockout mouse hippocampus has higher GluN2A mRNA levels (27). However, we excluded the possibility that the higher susceptibility of $\mathrm{PrP}^{\mathrm{C}}$-null mouse $\mathrm{OHC}$ was due to an overexpression of NMDAR at synapses, as we revealed comparable levels of interaction between PSD95 and Glu$\mathrm{N} 2 \mathrm{~A}$, and indirectly with GluN1, in wild-type and $\operatorname{PrP}^{\mathrm{C}}$-null mouse hippocampi.

By measuring GluN2A and GluN1 S-nitrosylation levels in CZ-treated wild-type and $\operatorname{PrP}^{\mathrm{C}}$-null mouse $\mathrm{OHC}$ by $\mathrm{CZ}$ addition, we found that copper chelation lowers GluN2A and GluN1 S-nitrosylation in wild-type cultures but not in $\operatorname{PrP}^{\mathrm{C}}$ null ones. The residual signal detected in wild-type upon copper deprivation was not different from that in treated and untreated $\operatorname{PrP}^{\mathrm{C}}$ knockout cultures.

In line with previously published electrophysiological recordings of NMDAR currents (40), our results on Snitrosylation highlight that $\operatorname{PrP}^{\mathrm{C}}$ regulation of NMDAR activity is copper dependent. Consistent with this fact, we found that also the neuroprotective effect of $\mathrm{PrP}^{\mathrm{C}}$ requires copper. These results convincingly indicate that in glutamatergic synapses, the neuroprotective action of $\mathrm{PrP}^{\mathrm{C}}$ depends on copper ions and that, vice versa, the neuroprotective action 


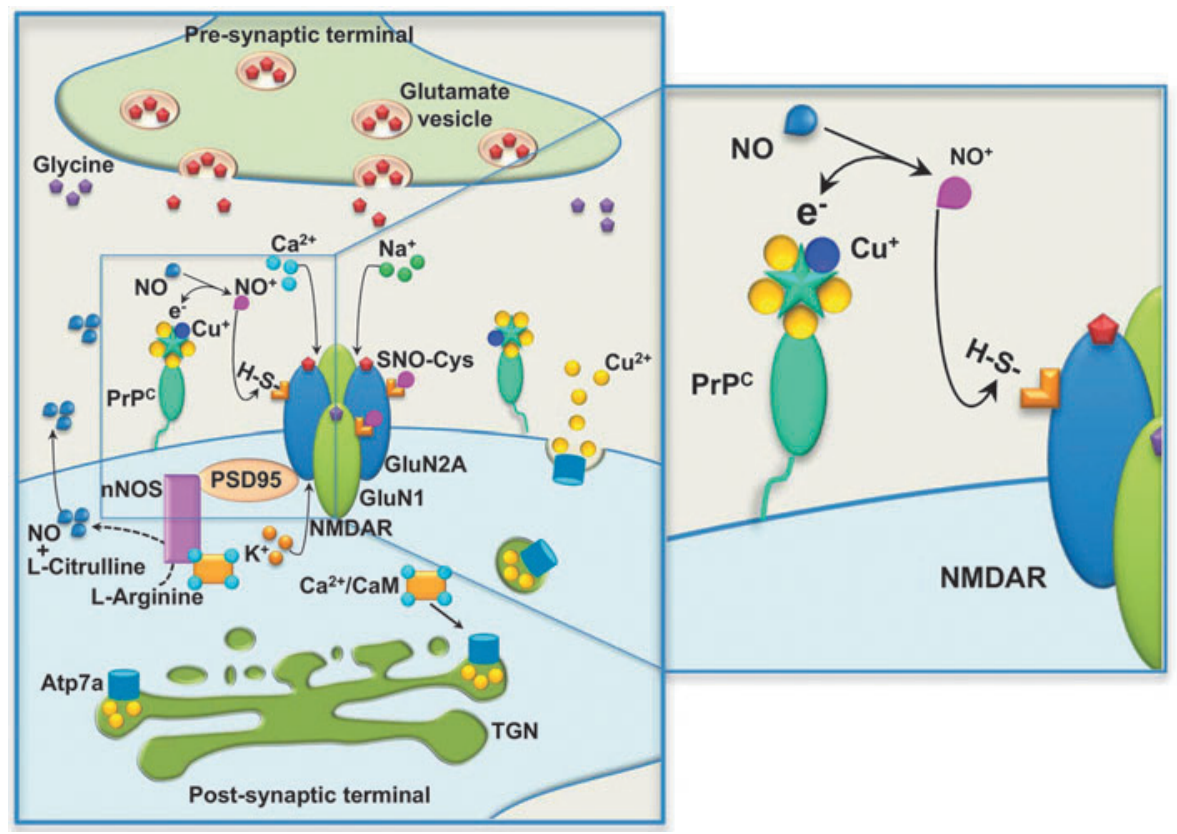

FIG. 7. Mechanism of PrP $^{\mathbf{C}}$-mediated S-nitrosylation of NMDAR. Glutamate released from the presynaptic terminal activates NMDAR on the postsynaptic terminal. NMDAR activation triggers $\mathrm{Na}^{+}$and $\mathrm{Ca}^{2+}$ influx, together with $\mathrm{K}^{+}$efflux. In the intracellular compartment, $\mathrm{Ca}^{2+}$ ions bind different proteins, including calmodulin $(\mathrm{CaM})$. The $\mathrm{Ca}{ }^{2+} / \mathrm{CaM}$ complex activates, among others, neuronal nitric oxide synthase (nNOS) and copper-transporting ATPase 1 (Atp7a): nNOS activation results in NO release in the synaptic cleft; Atp7a activation in the trans-Golgi network (TGN) results in $\mathrm{Cu}^{2+}$ release in the synaptic cleft. Released $\mathrm{Cu}^{2+}$ ions are immediately bound by copper-binding proteins: $\operatorname{PrP}^{\mathrm{C}}$ is highly expressed in both presynaptic and postsynaptic terminals, and it can be included in lipid raft domains that also contain NMDARs, and it has high affintiy for both $\mathrm{Cu}^{2+}$ and $\mathrm{Cu}^{+}$. Released NO can react with extracellular cysteines thiols of NMDAR subunits GluN1 and GluN2A, leading to cysteines S-nitrosylation (SNO-Cys). The S-nitrosylation inhibits NMDAR activation by closing the channel. The chemical reaction between NO and the cystein thiol requires the presence of an electron acceptor, often represented by $\mathrm{Cu}^{2+}$. According to this model, $\mathrm{PrP}^{\mathrm{C}}$ brings the $\mathrm{Cu}^{2+}$ ions that support the reaction of $\mathrm{NO}$ with thiols, leading to the S-nitrosylation of GluN1 and GluN2A, thus inhibiting NMDAR. To see this illustration in color, the reader is referred to the web version of this article at www.liebertpub.com/ars

of copper relies on $\mathrm{PrP}^{\mathrm{C}}$ expression. This finding has relevant implications in defining copper-mediated modulation of NMDAR and the involvement of copper in neuroprotection, as these functions are impaired in both $\mathrm{AD}$ and prion diseases. Moreover, it is known that copper metabolism dysfunction is a primary cause of other pathologies, such as Menkes' disease (MD)—a disorder caused by a loss-offunction mutation in the Atp7a-encoding gene that results in altered copper trafficking (26). Indeed, hippocampal neurons derived from a MD murine model have shown altered NMDAR current and increased damage upon excitotoxic stimulus (37). Strikingly, this phenotype is very similar to that observed in $\operatorname{PrP}^{\mathrm{C}}$-null models $(21,34,38)$.

Our findings indicate that $\mathrm{PrP}^{\mathrm{C}}$, copper, and $\mathrm{NO}$ regulate NMDAR and impart neuroprotection through a common mechanism that is likely to be lost in $\mathrm{AD}, \mathrm{MD}$, and prion diseases, thus leading to synapse degeneration. In this mechanism, $\operatorname{PrP}^{\mathrm{C}}$-bound copper ions act as electron acceptors in the reaction between NO and NMDAR cysteine thiols. The ensuing S-nitrosylation inhibits the receptor and reduces the neurotoxic effect caused by its overactivation. This mechanism is neuroprotective and crucial for normal synaptic functionality.

As in the case of NMDAR, $\operatorname{PrP}^{\mathrm{C}}-\mathrm{Cu}$ may also promote the $\mathrm{S}$-nitrosylation of other membrane proteins. Indeed, inducing protein S-nitrosylation may be an overarching function of $\mathrm{PrP}^{\mathrm{C}}$. The novel mechanism presented here may provide a platform to investigate additional and previously unforeseen cellular processes in which $\operatorname{PrP}^{\mathrm{C}}$ may be involved.

\section{Materials and Methods}

\section{Animals}

All experiments were performed in accordance with European regulations (European Community Council Directive, November 24, 1986 [86/609/EEC]). Experimental procedures were notified to and approved by the Italian Ministry of Health, Directorate General for Animal Health. All experiments were approved by the local authority veterinary service of Trieste, Italy, and by the Ethics Committee of the Scuola Internazionale Superiore di Studi Avanzati (SISSA), Trieste. All efforts were made to minimize animal suffering and to reduce the number of animals used. Inbred FVB/N (Friend virus B-type susceptibility-NIH) wild-type and FVB Prnp ${ }^{0 / 0}$ mice were used in these experiments. The FVB Prnp ${ }^{0 / 0}$ mice were obtained from George A. Carlson, McLaughlin Research Institute (Great Falls, MT) and were bred by backcrossing with the original Prnp ${ }^{0 / 0}$ mice at least 20 times (25).

\section{S-nitrosylated protein detection: biotin switch assay}

The biotin switch assay was performed, as described by Jaffrey and Snyder (18) with a few modifications. Mouse 
hippocampal samples (age-matched samples from 6-, 10-, and 12-month-old male animals) were dissected, immediately frozen in liquid nitrogen, and stored at $-80^{\circ} \mathrm{C}$. Each hippocampus was homogenized in $400 \mu \mathrm{l}$ HEN buffer: 250 mM HEPES pH 7.5 (H3375; Sigma-Aldrich, St Louis, MO), $1 \mathrm{~m} M$ EDTA (E6758; Sigma-Aldrich), $0.1 \mathrm{~m} M$ neocuproine (N1501; Sigma-Aldrich), protease inhibitors cocktail (Roche Diagnostics Corp., Mannheim, Germany), and centrifuged at $2000 \mathrm{~g}, 10 \mathrm{~min}$ at $4^{\circ} \mathrm{C}$. To evaluate the role of copper in NMDAR S-nitrosylation, Prnp $^{+/+}$and Prnp $^{0 / 0} \mathrm{OHC}$ were treated for $3 \mathrm{~h}$ with $20 \mu M \mathrm{CZ}$ (14690; Sigma-Aldrich) from the $4 \mathrm{~m} M$ stock in $50 \%$ ethanol, then immediately frozen. For each experiment, at least 60 slices per group were collected and homogenized in $100 \mu \mathrm{l} \mathrm{HEN}$ buffer by sonication. Protein concentration in the supernatant was determined by bicinchoninic acid assay and the same amount of proteins per sample was used for the further steps of the protocol (1 mg for hippocampal samples and $0.7-1 \mathrm{mg}$ for OHC depending on the lowest sample concentration in each experiment). All the reagents were used proportionally. Samples were diluted to $0.8 \mu \mathrm{g} / \mu \mathrm{l}$ in HEN buffer $+0.04 \%$ CHAPS (C9426; SigmaAldrich) and incubated at $50^{\circ} \mathrm{C}$ for $1 \mathrm{~h}$ in 4 volumes of blocking solution: 9 volumes of HEN, 1 volume of $25 \% \mathrm{w} / \mathrm{v}$ SDS (L3771; Sigma-Aldrich) in $\mathrm{ddH}_{2} \mathrm{O}$, and $20 \mathrm{~m} M$ S-methyl thiomethanesulfonate (64306; Sigma-Aldrich) from the $2 M$ stock solution in dimethylformamide. S-methyl thiomethanesulfonate was removed by acetone precipitation and the protein pellet was resuspended in $100 \mu$ of HENS buffer (HEN $+1 \%$ SDS) per mg of starting proteins. To selectively and efficiently reduce S-nitrosylated thiols, ascorbate (A4034; SigmaAldrich), prepared as $180 \mathrm{mM}$ in $\mathrm{ddH}_{2} \mathrm{O}$, was added to $30 \mathrm{mM}$ final concentration in the samples, and the reaction was carried out for $3 \mathrm{~h}$ at $25^{\circ} \mathrm{C}$ (14). A negative control without ascorbate was performed on Prnp ${ }^{+/+}$samples to check the efficiency of thiols blocking with S-methyl thiomethanesulfonate. Ascorbate was removed by acetone precipitation and the protein pellet was resuspended in $100 \mu \mathrm{l}$ of HENS buffer per mg of starting proteins. EZ-Link HPDP-biotin (21341; Thermoscientific, Waltham, MA) was used to bind free thiols, corresponding to the previously S-nitrosylated residues. It was added 1:3 to the samples from the $4 \mathrm{~m} M$ stock in dimethylformamide. A negative control without biotin was performed on Prnp $^{+/+}$samples to check the selective binding to the resin. After $1 \mathrm{~h}$ incubation at $25^{\circ} \mathrm{C}$, HPDP-biotin was removed by dialysis in HENS buffer. To purify biotinylated proteins, 2 volumes of neutralization buffer (20 m $M$ HEPES pH 7.5, $100 \mathrm{~m} M \mathrm{NaCl}$, $1 \mathrm{~m} M$ EDTA, 0.5\% Triton X-100 [X100; Sigma-Aldrich]) and $50 \mu \mathrm{l}$ of wet Immobilized NeutrAvidin Agarose (29200; Thermoscientific) were added to the samples and incubated for $2 \mathrm{~h}$ at room temperature (RT). Resin was washed 5 times with neutralization buffer adjusted to $600 \mathrm{mM} \mathrm{NaCl}$; biotinylated proteins were eluted directly in SDS-PAGE sample buffer, boiled, and processed for Western blot detection. For each sample, $30 \mu \mathrm{g}$ of protein extract were loaded as input. The following primary antibodies were used: anti-GluN1 1:5001:2000 (G8913; Sigma-Aldrich); anti-GluN2A 1:500-1:2000 (G9038; Sigma-Aldrich); monoclonal anti-PrP SHA31 $1 \mu \mathrm{g} /$ ml (A03213; BertinPharma, Montigny le Bretonneux, France); anti- $\beta$-actin Peroxidase (AC-15) 1:10,000 (A3854; SigmaAldrich). After incubation with the secondary antibody, membranes were developed with the ECL detection reagent (GE Healthcare, Waukesha, WI) and recorded by the digital imaging system Alliance 4.7 (UVITEC, Cambridge, United Kingdom). Band quantification was performed with Uviband 15.0 software (UVITEC) obtaining an optical density (OD) value. To normalize OD values, the following formula was applied: (NMDAR subunit S-nitrosylation/input) $/(\beta$-actin Snitrosylation/input). Basically, S-nitrosylation signals were normalized on the corresponding input. Then, NMDAR subunit values were normalized on $\beta$-actin value. Prnp $^{+/+}$and $P_{r n p}{ }^{0 / 0}$ samples were compared by the Mann-Whitney test setting $\mathrm{F}(\mathrm{x})<>\mathrm{G}(\mathrm{x})$ as alternate hypothesis.

\section{Organotypic hippocampal cultures preparation and treatments}

OHC preparation protocol was set up based on Gahwiler's protocol (13). Briefly, in aseptic condition, P5 mouse hippocampus was dissected in the dissection medium (Gey's balanced salt solution, 5.6 mM D-glucose [G8270; SigmaAldrich], $1 \mathrm{~m} M$ kynurenic acid [K3375; Sigma-Aldrich]) and sliced by means of a tissue chopper into 300- $\mu$ m-thick sections. After washing in the dissection medium for $40 \mathrm{~min}$ at $4^{\circ} \mathrm{C}$, slices showing an intact hippocampal cytoarchitecture were selected, singularly attached to a coverslip by embedding in a chicken plasma (P3266; Sigma-Aldrich) and thrombin clot (112374; Merck KGaA, Darmstadt, Germany) and maintained at 10 rotations per hour at $37^{\circ} \mathrm{C}$ in Nunc cell culture tubes (156758; Thermoscientific) with a medium composed of $50 \%$ basal medium Eagle (41010026; Gibco, Carlsbad, CA), 25\% horse serum (26050-088; Gibco), 25\% Hank's balanced salt solution (24020141; Gibco), 5.6 mM Dglucose, $2 \mathrm{~m} M$ L-glutamine (25030-032; Gibco). After 13 days in vitro, OHC were treated in the serum-free medium, as described in Supplementary Table S1. The drug stock solutions were prepared as follows: $1 \mathrm{mM}$ NMDA (0114; Tocris Biosciences, Missouri, United Kingdom) in $\mathrm{ddH}_{2} \mathrm{O}$ stored at $-20^{\circ} \mathrm{C}$; $250 \mathrm{~m} M$ EGTA (E4378; Sigma-Aldrich) in phosphate-buffered saline (PBS), pH 7.4, stored at RT; $40 \mathrm{mM}$ CNQX (C239; Sigma-Aldrich) in dimethyl sulfoxide (DMSO, D8418; Sigma-Aldrich) stored at $-20^{\circ} \mathrm{C} ; 10 \mathrm{mM}$ (2R)-amino-5-phosphonovaleric acid (AP5, A5282; SigmaAldrich) in $\mathrm{dd}_{2} \mathrm{O}$ stored at $-20^{\circ} \mathrm{C} ; 5 \mathrm{mM}$ threo ifenprodil hemitartrate (2892; Tocris Biosciences) in $\mathrm{ddH}_{2} \mathrm{O}$ stored at $20^{\circ} \mathrm{C}$; $10 \mathrm{~m} M$ GSNO (N4148; Sigma-Aldrich) in $\mathrm{dd}_{2} \mathrm{O}$ stored at $-20^{\circ} \mathrm{C}$; freshly prepared three NNA (N5501; Sigma-Aldrich) in serum-free medium; freshly prepared $4 \mathrm{mM}$ $\mathrm{CZ}$ in $50 \%$ ethanol. To induce excitotoxicity, $\mathrm{OHC}$ were exposed either to $5 \mu M$ NMDA for $3 \mathrm{~h}$ or to $10 \mu M$ NMDA for $10 \mathrm{~min}$. Experiments with EGTA were performed using $2 \mathrm{~m} M$ EGTA in combination with either $5 \mu M$ NMDA for $1.5 \mathrm{~h}$ (EGTA treatment for $3 \mathrm{~h}$ was toxic for $\mathrm{OHC}$ ) or $10 \mu \mathrm{M}$ NMDA for $10 \mathrm{~min}$. Treatments with $5 \mu M$ NMDA in combination with either $50 \mu M$ AP5 or $20 \mu M$ CNQX or $20 \mu M$ GSNO or $1 \mathrm{~m} M$ NNA or $20 \mu M \mathrm{CZ}$ were incubated for $3 \mathrm{~h}$. To obtain a more complete inhibition, AP5, CNQX, and NNA were preincubated for $30 \mathrm{~min}$ before adding NMDA. Treatments with NMDA and ifenprodil were carried out differently because of the toxic effect of ifenprodil when associated to low NMDA concentrations (20). For this reason, OHC were exposed to $10 \mu M$ NMDA and $3 \mu M$ ifenprodil for $10 \mathrm{~min}$. To evaluate neuronal cell death, all the described treatments were followed by a $24 \mathrm{~h}$ washout before processing $\mathrm{OHC}$ for immunofluorescence. 


\section{Immunofluorescence}

To evaluate neuronal cell death, slices were fixed in $4 \%$ paraformaldehyde (P6148; Sigma-Aldrich) in PBS, pH 7.4, $\mathrm{O} / \mathrm{N}$ at $4{ }^{\circ} \mathrm{C}$. To improve the nuclear staining, slices were treated as follows: $3 \times 5$ min washes in PBS with $1 \%$ Triton $\mathrm{X}-100,10 \mathrm{~min}$ in $0.1 \mathrm{~N} \mathrm{HCl}$ at $4^{\circ} \mathrm{C}, 10 \mathrm{~min}$ in $0.2 \mathrm{~N} \mathrm{HCl}$ at $\mathrm{RT}, 20 \mathrm{~min}$ in $0.2 \mathrm{~N} \mathrm{HCl}$ at $37^{\circ} \mathrm{C}, 12 \mathrm{~min}$ in borate buffer $\mathrm{pH}$ 8.4 at RT, $3 \times 5$ min washes in PBS with $1 \%$ Triton $\mathrm{X}-100$. Slices were incubated for $2 \mathrm{~h}$ at RT in the blocking solution (1 $M$ glycin [G8898; Sigma-Aldrich], 5\% normal goat serum [005-000-121; Jackson ImmunoResearch] in PBS with 1\% Triton $\mathrm{X}-100$ ) and $\mathrm{O} / \mathrm{N}$ at $4^{\circ} \mathrm{C}$ with anti-neuronal nuclei (NeuN) clone A60 antibody 1:500 (mab377; Millipore, Billerica, MA) in the blocking solution. After washing with PBS and $1 \%$ Triton X100 , slices were incubated with Alexa fluorophore-conjugated secondary antibodies (1:500, R37120; Invitrogen, Carlsbad, CA) and 4',6-diamidino-2-phenylindole (DAPI, 1:500) in the blocking solution for $2 \mathrm{~h}$ at RT. Slices were washed in PBS, rinsed in water, and mounted with VectaShield (Vector Laboratories, Burlingame, CA).

\section{Confocal microscopy, image analysis, and statistics of $\mathrm{OHC}$ experiments}

Immunofluorescence images were acquired on a Leica DMIRE2 confocal microscope (Leica Microsystem GmbH, Wetzlar, Germany) equipped with DIC and fluorescent optics, diode laser $405 \mathrm{~nm}$, and $\mathrm{Ar} / \mathrm{ArKr} 488 \mathrm{~nm}$ lasers. The fluorescence images $(1024 \times 1024$ pixels $)$ were acquired with a $40 \times / 1.30$ NA oil objective, additionally zoomed 1.5 -fold, with $200 \mathrm{~Hz}$ acquisition speed. Stacks of z-sections with an interval of $3 \mu \mathrm{m}$ were sequentially scanned. CA1, CA3, and DG were the regions selected for the analysis. A protocol for automatic count of the total amount of nuclei was set up for each hippocampal zone with the Volocity 5.4 3D imaging software (PerkinElmer, Coventry, United Kingdom). The same software was used to manually count the pyknotic nuclei. The dead cell count was performed as a blind analysis. The CA1, CA3, and DG regions were clearly distinguishable in $\mathrm{OHC}$ used in these experiments (Supplementary Fig. S11A) and the staining protocol allowed for the exact identification of neuronal pyknotic nuclei (Supplementary Fig. S11B). Pyknotic nuclei count results for Prnp ${ }^{+/+}$and Prnp ${ }^{0 / 0}$ $\mathrm{OHC}$ were compared by performing the Mann-Whitney test setting $\mathrm{F}(\mathrm{x})<>\mathrm{G}(\mathrm{x})$ as alternate hypothesis. Each culture preparation (resulting from three to four mice dissection) was considered as one sample $(n=1)$. In each culture, the average pyknotic nuclei percentage among the hippocampal slices (four to five slices) of the same treatment group was calculated, grouped with values obtained from other $\mathrm{OHC}$ of the same genotype with the same treatment for a final sample size of four $(n=4)$ and compared with the other treatments and genotype by means of the Mann-Whitney test.

\section{Acknowledgments}

This work was supported by a grant from the Italian Ministry for Education, University and Research to G.L. (Grant MIUR-PRIN 2010/2011-A.AC.NSCI.780). F.B. gratefully acknowledges the International School for Advanced Studies (SISSA), Trieste, for partially supporting this work through the "Young SISSA Scientists' Research Pro- jects" 2011-2012 scheme. The authors are grateful to Diego Favretto, Sara De Iudicibus, and Prof. Giuliana Decorti (Department of Life Sciences, University of Trieste) for their expertise in the analytical measurement of the NOS activity with radioactive substrate. The authors thank Prof. Enrico Cherubini for helpful scientific discussion and suggestions, Roberta Antonelli for her assistance in coIP experiments, and Erica Sarnataro for editing and proofreading the article.

\section{Author Disclosure Statement}

The authors declare no competing financial interests exist.

\section{References}

1. Aguzzi A, Baumann F, and Bremer J. The prion's elusive reason for being. Annu Rev Neurosci 31: 439-477, 2008.

2. Benetti F, Ventura M, Salmini B, Ceola S, Carbonera D, Mammi S, Zitolo A, D'Angelo P, Urso E, Maffia M, Salvato B, and Spisni E. Cuprizone neurotoxicity, copper deficiency and neurodegeneration. Neurotoxicology 31: 509-517, 2010.

3. Benvegnu S, Poggiolini I, and Legname G. Neurodevelopmental expression and localization of the cellular prion protein in the central nervous system of the mouse. J Comp Neurol 518: 1879-1891, 2010.

4. Bonomo RP, Pappalardo G, Rizzarelli E, Tabbi G, and Vagliasindi LI. Studies of nitric oxide interaction with mono- and dinuclear copper(II) complexes of prion protein bis-octarepeat fragments. Dalton Trans 3805-3816, 2008.

5. Brown DR, Qin K, Herms JW, Madlung A, Manson J, Strome R, Fraser PE, Kruck T, von Bohlen A, SchulzSchaeffer W, Giese A, Westaway D, and Kretzschmar H. The cellular prion protein binds copper in vivo. Nature 390: 684-687, 1997.

6. Caiati MD, Safiulina VF, Fattorini G, Sivakumaran S, Legname G, and Cherubini E. PrPC controls via protein kinase A the direction of synaptic plasticity in the immature hippocampus. J Neurosci 33: 2973-2983, 2013.

7. Choi YB, Tenneti L, Le DA, Ortiz J, Bai G, Chen HS, and Lipton SA. Molecular basis of NMDA receptor-coupled ion channel modulation by S-nitrosylation. Nat Neurosci 3: 1521, 2000.

8. D'Angelo P, Della Longa S, Arcovito A, Mancini G, Zitolo A, Chillemi G, Giachin G, Legname G, and Benetti F. Effects of the pathological Q212P mutation on human prion protein non-octarepeat copper-binding site. Biochemistry 51: 6068-6079, 2012.

9. Delint-Ramirez I, Fernandez E, Bayes A, Kicsi E, Komiyama $\mathrm{NH}$, and Grant SG. In vivo composition of NMDA receptor signaling complexes differs between membrane subdomains and is modulated by PSD-95 and PSD-93. J Neurosci 30: 8162-8170, 2010.

10. Dong Z, Saikumar P, Weinberg JM, and Venkatachalam MA. Calcium in cell injury and death. Annu Rev Pathol 1: 405-434, 2006.

11. Foster MW, McMahon TJ, and Stamler JS. S-nitrosylation in health and disease. Trends Mol Med 9: 160-168, 2003.

12. Fournier JG, Escaig-Haye F, Billette de Villemeur T, Robain O, Lasmezas CI, Deslys JP, Dormont D, and Brown P. Distribution and submicroscopic immunogold localization of cellular prion protein $(\mathrm{PrPc})$ in extracerebral tissues. Cell Tissue Res 292: 77-84, 1998.

13. Gahwiler BH, Capogna M, Debanne D, McKinney RA, and Thompson SM. Organotypic slice cultures: a technique has come of age. Trends Neurosci 20: 471-477, 1997. 
14. Gow AJ and Ischiropoulos H. Nitric oxide chemistry and cellular signaling. J Cell Physiol 187: 277-282, 2001.

15. Greenough MA, Camakaris J, and Bush AI. Metal dyshomeostasis and oxidative stress in Alzheimer's disease. Neurochem Int 62: 540-555, 2013.

16. Hardingham GE and Bading H. Synaptic versus extrasynaptic NMDA receptor signalling: implications for neurodegenerative disorders. Nat Rev Neurosci 11: 682-696, 2010.

17. Hess DT, Matsumoto A, Kim SO, Marshall HE, and Stamler JS. Protein S-nitrosylation: purview and parameters. Nat Rev Mol Cell Biol 6: 150-166, 2005.

18. Jaffrey SR and Snyder SH. The biotin switch method for the detection of S-nitrosylated proteins. Sci STKE 2001: pl1, 2001.

19. Kellett KA and Hooper NM. Prion protein and Alzheimer disease. Prion 3: 190-194, 2009.

20. Kew JN, Trube G, and Kemp JA. A novel mechanism of activity-dependent NMDA receptor antagonism describes the effect of ifenprodil in rat cultured cortical neurones. $J$ Physiol 497 (Pt 3): 761-772, 1996.

21. Khosravani H, Zhang Y, Tsutsui S, Hameed S, Altier C, Hamid J, Chen L, Villemaire M, Ali Z, Jirik FR, and Zamponi GW. Prion protein attenuates excitotoxicity by inhibiting NMDA receptors. J Cell Biol 181: 551-565, 2008.

22. Kone BC, Kuncewicz T, Zhang W, and Yu ZY. Protein interactions with nitric oxide synthases: controlling the right time, the right place, and the right amount of nitric oxide. Am J Physiol Renal Physiol 285: F178-F190, 2003.

23. Lipton SA, Choi YB, Takahashi H, Zhang D, Li W, Godzik $\mathrm{A}$, and Bankston LA. Cysteine regulation of protein function-as exemplified by NMDA-receptor modulation. Trends Neurosci 25: 474-480, 2002.

24. Liu L, Jiang D, McDonald A, Hao Y, Millhauser GL, and Zhou F. Copper redox cycling in the prion protein depends critically on binding mode. J Am Chem Soc 133: 1222912237, 2011.

25. Lledo PM, Tremblay P, DeArmond SJ, Prusiner SB, and Nicoll RA. Mice deficient for prion protein exhibit normal neuronal excitability and synaptic transmission in the hippocampus. Proc Natl Acad Sci U S A 93: 2403-2407, 1996.

26. Lutsenko $S$ and Petris MJ. Function and regulation of the mammalian copper-transporting ATPases: insights from biochemical and cell biological approaches. J Membr Biol 191: 1-12, 2003.

27. Maglio LE, Perez MF, Martins VR, Brentani RR, and Ramirez OA. Hippocampal synaptic plasticity in mice devoid of cellular prion protein. Brain Res Mol Brain Res 131: 58-64, 2004.

28. Mallucci GR, Ratte S, Asante EA, Linehan J, Gowland I, Jefferys JG, and Collinge J. Post-natal knockout of prion protein alters hippocampal CA1 properties, but does not result in neurodegeneration. EMBO J 21: 202-210, 2002.

29. Mani L, Cheng F, Havsmark B, Jonsson M, Belting M, and Fransson L. Prion, amyloid-derived Cu(II) ions, or free $\mathrm{Zn}$ (II) ions support S-nitroso-dependent autocleavage of glypican-1 heparan sulfate. J Biol Chem 278: 38956-38965, 2003.

30. McBain CJ and Mayer ML. N-methyl-D-aspartic acid receptor structure and function. Physiol Rev 74: 723-760, 1994.

31. Moya KL, Sales N, Hassig R, Creminon C, Grassi J, and Di Giamberardino L. Immunolocalization of the cellular prion protein in normal brain. Microsc Res Tech 50: 58-65, 2000.

32. Naslavsky N, Stein R, Yanai A, Friedlander G, and Taraboulos A. Characterization of detergent-insoluble complexes containing the cellular prion protein and its scrapie isoform. J Biol Chem 272: 6324-6331, 1997.
33. Prusiner SB. Shattuck lecture-neurodegenerative diseases and prions. N Engl J Med 344: 1516-1526, 2001.

34. Rangel A, Burgaya F, Gavin R, Soriano E, Aguzzi A, and Del Rio JA. Enhanced susceptibility of Prnp-deficient mice to kainate-induced seizures, neuronal apoptosis, and death: Role of AMPA/kainate receptors. J Neurosci Res 85: 2741 2755, 2007.

35. Sales N, Rodolfo K, Hassig R, Faucheux B, Di Giamberardino $\mathrm{L}$, and Moya KL. Cellular prion protein localization in rodent and primate brain. Eur J Neurosci 10: 2464-2471, 1998.

36. Schlief ML, Craig AM, and Gitlin JD. NMDA receptor activation mediates copper homeostasis in hippocampal neurons. J Neurosci 25: 239-246, 2005.

37. Schlief ML, West T, Craig AM, Holtzman DM, and Gitlin JD. Role of the Menkes copper-transporting ATPase in NMDA receptor-mediated neuronal toxicity. Proc Natl Acad Sci U S A 103: 14919-14924, 2006.

38. Spudich A, Frigg R, Kilic E, Kilic U, Oesch B, Raeber A, Bassetti CL, and Hermann DM. Aggravation of ischemic brain injury by prion protein deficiency: role of ERK-1/-2 and STAT-1. Neurobiol Dis 20: 442-449, 2005.

39. Wroge CM, Hogins J, Eisenman L, and Mennerick S. Synaptic NMDA receptors mediate hypoxic excitotoxic death. J Neurosci 32: 6732-6742, 2012.

40. You H, Tsutsui S, Hameed S, Kannanayakal TJ, Chen L, Xia P, Engbers JD, Lipton SA, Stys PK, and Zamponi GW. Abeta neurotoxicity depends on interactions between copper ions, prion protein, and N-methyl-D-aspartate receptors. Proc Natl Acad Sci U S A 109: 1737-1742, 2012.

41. Zhou X, Ding Q, Chen Z, Yun H, and Wang H. Involvement of the GluN2A and GluN2B subunits in synaptic and extrasynaptic N-methyl-D-aspartate receptor function and neuronal excitotoxicity. J Biol Chem 288: 24151-24159, 2013.

42. Zhou X, Hollern D, Liao J, Andrechek E, and Wang H. NMDA receptor-mediated excitotoxicity depends on the coactivation of synaptic and extrasynaptic receptors. Cell Death Dis 4: e560, 2013.

$$
\begin{array}{r}
\text { Address correspondence to: } \\
\text { Dr. Federico Benetti } \\
\text { ECSIN-European Center for the Sustainable } \\
\text { Impact of Nanotechnology } \\
\text { Veneto Nanotech S.C.p.A. } \\
\text { Viale Porta Adige } 45 \\
\text { Rovigo 45100 } \\
\text { Italy } \\
\text { E-mail: benetti@ sissa.it } \\
\text { Prof. Giuseppe Legname } \\
\text { Laboratory of Prion Biology } \\
\text { Department of Neuroscience } \\
\text { Scuola Internazionale Superiore } \\
\text { di Studi Avanzati (SISSA) } \\
\text { Via Bonomea 265 } \\
\text { Trieste 34136 } \\
\text { Italy }
\end{array}
$$

E-mail: legname@sissa.it

Date of first submission to ARS Central, June 25, 2014; date of final revised submission, November 5, 2014; date of acceptance, December 8, 2014. 


$\begin{aligned} & \text { Abbreviations Used } \\ \mathrm{AD} & =\text { Alzheimer disease } \\ \mathrm{AP} 5 & =(2 R) \text {-amino-5-phosphonovaleric acid } \\ \mathrm{Atp} 7 \mathrm{a} & =\text { copper-transporting ATPase } 1 \\ \mathrm{CA} 1 & =\text { Cornus Ammonis } 1 \\ \mathrm{CA} 3 & =\text { Cornus Ammonis } 3 \\ \mathrm{CaM} & =\text { calmodulin } \\ \mathrm{CNQX} & =6 \text {-cyano-7-nitroquinoxaline-2,3-dione } \\ \mathrm{COIP} & =\text { co-immunoprecipitation } \\ \mathrm{CZ} & =\text { cuprizone } \\ \mathrm{DAPI} & =4^{\prime}, 6 \text {-diamidino-2-phenylindole } \\ \mathrm{DG} & =\text { dentate gyrus } \\ \mathrm{DMSO} & =\text { dimethyl sulfoxide } \\ \mathrm{EGTA} & =\text { ethylene glycol tetraacetic acid } \\ \mathrm{GluN} 1 & =\text { NMDAR subunit GluN1 } \\ \mathrm{GluN} 2 \mathrm{~A} & =\text { NMDAR subunit GluN2A }\end{aligned}$

\begin{tabular}{|c|}
\hline 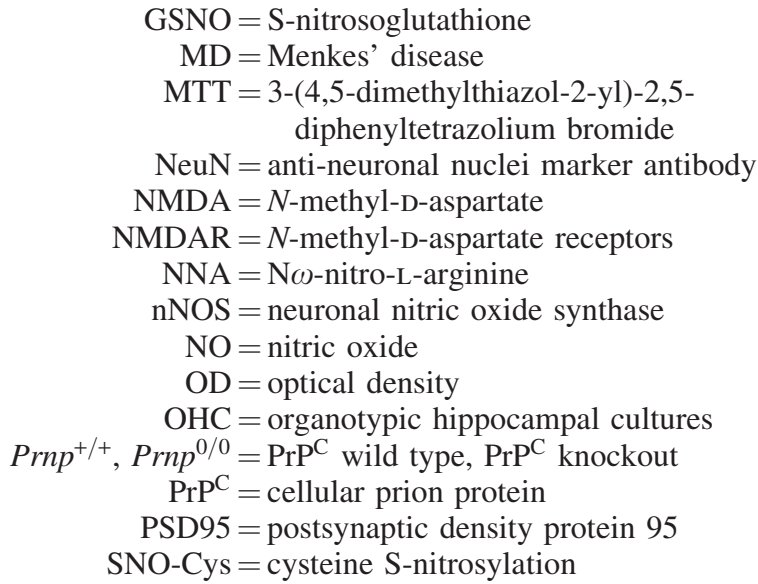 \\
\hline
\end{tabular}

